\title{
TITLE:
}

\section{Cellulase activity in meiobenthos in wetlands}

AUTHOR(S):

Toyohara, Haruhiko; Park, Younghwa; Tsuchiya, Kanako; Liu, Wen

\section{CITATION:}

Toyohara, Haruhiko ...[et al]. Cellulase activity in meiobenthos in wetlands. Fisheries Science 2012, 78(1): 133-137

ISSUE DATE:

2012-01

URL:

http://hdl.handle.net/2433/152545

\section{RIGHT:}

The final publication is available at www.springerlink.com; この論文は 出版社版でありません。引用の際には出版社版をご確認ご利用くださ $\omega_{\circ}$; This is not the published version. Please cite only the published version. 
1 Cellulase Activity in Meiobenthos in Wetlands

2

3 Haruhiko Toyohara* $\cdot$ Younghwa Park $\cdot$ Kanako Tsuchiya $\cdot$ Wen Liu

4

5 Division of Applied Biosciences, Graduate School of Agriculture, Kyoto University,

6 Kyoto 606-8502, Japan

7

8 Corresponding author

$9 \quad$ Haruhiko Toyohara

10 Tel/Fax: 81-075-753-6446

11 Email: toyohara@kais.kyoto-u.ac.jp

12 


\section{Abstract}

14 To validate the involvement of meiobenthos in cellulose breakdown in wetlands,

15 meiobenthos were collected from the sediments of Lake Furen and the Biwase River in

16 Hokkaido prefecture, the Kako River in Hyogo prefecture, and the Chinai River in

17 Shiga prefecture. Cellulase activities of the meiobenthos were measured by cellulose zymographic analysis using SDS-PAGE gels containing $0.5 \%$ carboxymethyl cellulose.

19 The results showed that most of the Turbellaria, Nematoda, Harpacticoida and

20 Oligochaeta species exhibited cellulase activity. The molecular sizes of the

21 cellulase-active bands of the sediments in Lake Furen, the Biwase River, and the Chinai

22 River coincided with those of meiobenthos. The findings suggest that meiobenthos

23 might play a major function in cellulose breakdown in these wetlands. This paper is the

24 first to report cellulase activity in meiobenthos and that they are possibly involved in the breakdown of cellulose in wetlands.

KEY WORDS: cellulase $\cdot$ cellulose $\cdot$ meiobenthos $\cdot$ sediment $\cdot$ wetland

\section{Introduction}


31 Cellulose, the most abundant organic matter on earth, is a high molecular weight

substance consisting of glucose residues bound by $\beta-1,4$ linkages, unlike starch, another glucan consisting of a $\alpha-1,4$ linked glucose residues. Cellulose is resistant to enzyme degradation $[1,2]$. However, cellulose can be degraded by specific enzymes collectively named cellulases [3].

Fungi and bacteria as well as symbiotic protozoa in herbivorous animals and termites have been studied as known consumers of cellulose [4]. Recently, an intrinsic cellulase gene was isolated from termite [5], and a variety of intrinsic cellulase genes were identified from various animals, including beetle [6], nematode [7, 8], abalone [9], mussel [10], sea urchin [11], and brackish-water clam [12]. Recent stable isotopic analysis showed that a brackish water clam Corbicula japonica consumes land-derived organic materials mainly composed of cellulose [13]. Identification of the intrinsic cellulase gene and immunological detection of the enzyme protein in $C$. japonica strongly suggest that $C$. japonica plays an important role in the process of degradation of cellulose in rivers [14].

Besides macrobenthos such as $C$. japonica, a group of small animals called meiobenthos also inhabits the sediments of aquatic areas. Meiobenthos are defined as 
48 animals that pass through a 1-mm mesh filter and are known to be composed of a variety of fauna corresponding to 22 phyla [15]. In the present study, we attempted to validate the role of meiobenthos in the process of breakdown of cellulose in wetlands. We chose Lake Furen and the Biwase River located in the subarctic area, since they were reported to be the wetlands demonstrating the highest cellulase activities in Japan [16]. On the other hand, we chose

54 the Kako River and the Chinai River as typical rivers in temperate area. We also expected the difference in distribution of meiobenthos between the Kako River and the

Chinai River, because the Chinai River is a fresh water river. We report that meiobenthos have cellulase activity and possibly play substantially important roles in the cellulose degradation process in the sediments of some wetlands.

Materials

63

We collected sediments from Lake Furen and the Biwase River in Hokkaido prefecture, the Kako River in Hyogo prefecture, and the Chinai River in Shiga prefecture. River 
66 sediments from all rivers were collected in the wetland within $50 \mathrm{~m}$ from the river mouth. From each site, we collected sediment samples from a 5-cm depth at low tide from May 2006 to October 2007. The sediment samples were transported to the laboratory in Kyoto University at $4^{\circ} \mathrm{C}$, and meiobenthos were recovered in the fraction that included material small enough to pass through a $1 \mathrm{~mm}$-mesh filter but too large to pass through a $40 \mu \mathrm{m}$-mesh filter. These meiobenthos were classified under microscopic observation according to Higgins and Thiel [15]. About $500 \mathrm{~g}$ of the sediments were filtered through $1 \mathrm{~mm}$-mesh. Sediment samples that were not filtered were designated "total sediment fraction," while sediments less than $1 \mathrm{~mm}$ and larger than $40 \mu \mathrm{m}$ were collected and designated "meiobenthos fraction."

Measurement of cellulase activity

Meiobenthos were separated from the sediments by using a pair of tweezers under the microscope (Olympus, S2X12, Tokyo), and each single meiobenthos was homogenized with $20 \mu \mathrm{l}$ of phosphate-buffered saline (PBS) containing $140 \mathrm{mM} \mathrm{NaCl}, 2.7 \mathrm{mM} \mathrm{KCl}$, $8 \mathrm{mM} \mathrm{Na}_{2} \mathrm{HPO}$, and $1.5 \mathrm{mM} \mathrm{KH}_{2} \mathrm{PO}_{4}(\mathrm{pH} 7.4)$ to prepare a meiobenthos extract. The total sediment and meiobenthos fractions were homogenized with 1.5-fold volume of 
84 PBS, and the supernatants were obtained by centrifugation at $10,000 \times g$ for $10 \mathrm{~min}$.

85 Ten microgram of the supernatant was applied on cellulase zymographic analysis.

86 Cellulase zymographic analysis was performed as described previously by using $7.5 \%$

87 or $10 \%$ SDS-PAGE gel containing $0.5 \%$ carboxymethyl cellulose (CMC, Sigma, St

88 Louis, MO, US). After electrophoresis, the gels were soaked in $10 \mathrm{mM}$ acetate buffer

89 (pH 5.5) containing $0.1 \%$ TritonX-100 for $30 \mathrm{~min}$ to remove SDS from the gels. The

90 gels were transferred to $10 \mathrm{mM}$ acetate buffer ( $\mathrm{pH} 5.5$ ), incubated at $37^{\circ} \mathrm{C}$ overnight,

91 and then stained with $0.1 \%$ Congo Red. The gels were destained using $1 \mathrm{M} \mathrm{NaCl}$. The

92 active bands were detected as non-stained bands. Unless otherwise specified, special

93 grades of reagents were commercially obtained from Nacalai Tesque (Kyoto). Protein

94 concentration was measured according to the method of Bradford (17).

95

96 Results

97

98 Distribution of meiobenthos

99

100 Oligochaeta species were the dominant meiobenthos in Lake Furen, where the

sediments are mainly composed of sand. In addition, a variety of Turbellaria, Nematoda, 
102 Harpacticoida species were also observed. Oligochaeta species were also dominant in

103 the Chinai River, where the sediments were, like in Lake Furen, mainly composed of

104 sand.

In the Biwase and Kako Rivers, where the sediments were mainly composed of

106 clay, Nematoda and Harpacticoida species were dominantly observed.

108 Cellulase activity of sediments and meiobenthos

110 Cellulase activity in meiobenthos extracts, total sediment fractions, and meiobenthos

111 fractions were measured by cellulose zymography.

$113 \quad 32.5 \mathrm{kDa}$ and $47.5 \mathrm{kDa}$ in samples from Lake Furen, which coincided with those of the

114 meiobenthos fraction (lanes 1 and 2 in Fig. 1). Oligochaeta species assayed by using a

115 single animal showed an active band corresponding to $32.5 \mathrm{kDa}$, which is the band size

116 observed for the total sediment fraction and the meiobenthos fraction (lane 3 in Fig. 1).

117 Different species of Nematoda showed active bands of different molecular sizes, as

118 shown in lanes 4-7 of Fig. 1. Interestingly, common active bands at $25 \mathrm{kDa}$ were

119 detected for all the Nematoda species. Various active bands were also detected for 
120 Turbellaria species (lane 8 in Fig. 1), but their sizes differed from those of Nematoda

121 species. approximately $5 \mathrm{mg}$ per one lane from the Biwase River. Intensive active bands were observed, especially above $47.3 \mathrm{kDa}$ in the total sediment fraction and the meiobenthos fraction (lanes 1 and 2 in Fig. 2), and the active band patterns were nearly identical. Harpacticoida species, the dominant organisms of meiobenthos in the Biwase River, also exhibited remarkably intensive activity bands of above $47.3 \mathrm{kDa}$ (lane 3 in Fig. 2). active bands were observed at $25 \mathrm{kDa}$ and between $47.5 \mathrm{kDa}$ and $62 \mathrm{kDa}$ in the total sediment fraction and the meiobenthos fraction (lanes 1 and 2 in Fig. 3). Bands with nearly the same activity were observed for Oligochaeta species, as shown in lane 3. sediment fraction and the meiobenthos fraction, faint bands of less than $25 \mathrm{kDa}$ were observed (lanes 1 and 2 in Fig. 4). In lane 3, active bands of Harpacticoida species were observed at approximately $47.5 \mathrm{kDa}$, which did not coincide with the active bands in the total sediment fraction and the meiobenthos fraction. 


\section{Discussion}

139 Cellulase activities were detected in the extracts of the meiobenthos collected from all

140 the sampling sites examined, suggesting that meiobenthos may be involved in the

141 breakdown of cellulose in the sediments. Interestingly, $25 \mathrm{kDa}$ active bands were

142 commonly detected in the extracts of morphologically distinct Nematoda species

143 collected from Lake Furen (lanes 4-7 in Fig. 1), suggesting that Nematoda species

144 possibly share a related cellulase gene. On the other hand, Oligochaeta species collected

145 from Lake Furen and the Chinai River were morphologically distinct and the band sizes

146 of the cellulase were also different (compare lane 3 in Fig. 1 and lane 3 in Fig. 3).

147 The International Collaborative Research on the Management of Wetland

148 Ecosystem of the National Institute for Environmental Studies [16] reported the

149 outstanding strong cellulase activities of sediments collected from Lake Furen and the

150 Biwase River in Hokkaido among many Japanese wetlands tested. The report attributed

151 the strong cellulase activity in the sediments of Lake Furen and the Biwase River to

152 microorganisms including bacteria and fungus. However, the active bands in cellulose zymographic analyses showed that the position of the active bands coincided with the sediment fractions and the extracts of meiobenthos (Figs. 1 and 2), which supported the 
155 hypothesis that meiobenthos might be involved in the breakdown of cellulose in Lake

156 Furen and the Biwase River.

Because recent molecular biological studies suggest the endogenous origin of the cellulase genes in aquatic invertebrates [9, 11, 12], cellulase genes of meiobenthos could be encoded in the DNA of meiobenthos themselves. We are now trying to clone the cellulase genes of meiobenthos to validate the possibility of its endogenous origin. As shown in Fig. 3, active bands of the total sediment fraction and the meiobenthos fraction coincided with those of Oligochaeta species from the Chinai River.

163 On the other hand, active bands of the total sediment fraction and the meiobenthos fraction did not coincide with those of the Harpacticoida species from the Kako River, as shown in Fig. 4. Thus, the origin of cellulase could not be concluded to be the meiobenthos in the case of Kako River sediment. Further studies are required to evaluate the contribution of meiobenthos to the breakdown of cellulose in wetlands in the temperate area. The contribution of termites to the breakdown of cellulose in the forests of tropical zones is assumed to correspond to $80 \%$ the total cellulose breakdown in this area [18]. Like termites, meiobenthos could be major consumers of cellulose, especially in some wetlands in Hokkaido, because cellulase activity of meiobenthos in Lake Furen 
173 and the Biwase River were detected at $4^{\circ} \mathrm{C}$ (data not shown), which is a temperature at

174 which the growth of bacteria and fungi would be suppressed. Therefore, it seems

175 probable that meiobenthos would play important roles in cellulose degradation

176 especially in low temperature environments like wetlands in Hokkaido.

179 Acknowledgements

180 This study was supported by a Grant-in-Aid for scientific research from the Ministry of

181 Education, Culture, Sports, Science and Technology of Japan (No. 22255012).

\section{References}

1. Cosgrove DJ (2005) Growth of the plant cell wall. Nat Rev Mol Cell Biol $6: 850-861$

2. Vries RP, Visser J (2001) Aspergillus enzymes involved in degradation of plant cell wall polysaccharides. Microbiol Rev 65:497-522.

3. Knowles J, Lehtovaara P, Teeri T (1987) Cellulase families and their genes. Tibtech $5: 255-261$

4. Watanabe H, Tokuda G (2001) Animal cellulases. Cell Mol Life Sci 58:1167-1178. 
191 5. Watanabe H, Noda H, Tokuda G, Lo N (1998) A cellulase gene of termite origin.

Nature 394:330-331.

193

6. Sugimura M, Watanabe H, Lo N, Saito H (2003) Purification, characterization, cDNA cloning and nucleotide sequencing of a cellulase from the yellow-spotted longicorn beetle, Psacothea hilaris. Eur J Biochem 270:3455-3460.

7. Smant G, Stokkermans PWGJ, Yan Y, Boer de MJ, Baum JT, Wang XH, Hussey RS, Endogenous cellulases in animals: Isolation of $\beta$-1,4-endoglucanase genes from two species of plant-parasitic cyst nematodes. Proc Natl Acad Sci USA 95:4905-4911.

8. Kikuchi T, Shibuya H, Jones TJ (2005) Molecular and biochemical characterization of an endo- $\beta-1,3$-glucanase from the pinewood nematode Bursaphelenchus xylophilus acquired by horizontal gene transfer from bacteria. Biochem $\mathbf{J}$ 389:117-125.

9. Suzuki K, Ojima T, Nishita K (2003) Purification and cDNA cloning of a cellulase from abalone Haliotis discus hannai. Eur J Biochem 270:771-778.

10. Guo R, Ding M, Zhang SL, Xu GJ, Zhao FK (2008) Molecular cloning and 
209 11. Nishida Y, Suzuki K, Kumagai Y, Tanaka H, Inoue A, Ojima T (2007) Isolation and

210 primary structure of a cellulase from the Japanese sea urchin Strongylocentrotus

$211 \quad$ nudus. Biochimie 89:1002-1011.

212 12. Sakamoto K, Touhata K, Yamashita M, Kasai A, Toyohara H (2007) Cellulose

213 digestion by common Japanese freshwater clam Corbicula japonica. Fish Sci

$214 \quad 73: 675-683$.

215 13. Kasai A, Nakata A (2005) Utilization of terrestrial organic matter by the bivalve

216 Corbicula japonica estimated from stable isotope analysis. Fish Sci 71:151-158.

217 14. Sakamoto K, Uji S, Kurokawa T, Toyohara H (2008) Immunohistochemical, in situ hybridization and biochemical studies on endogenous cellulase of Corbicula japonica. Comp Biochem Physiol Part B 150:216-221.

15. Higgins RP, Thiel H (1988) Introduction to the study of meiofauna. Smithsonian Institution Press.

16. National Institute for Environmental Studies, Japan (2003) International collaborative research on the management of wetland ecosystem. Report of special research from the National Institute for Environmental Studies, Japan, pp 8-13. 
225 17. Bradford MM (1976) Rapid and sensitive method for the quantitation of microgram

226 quantities of protein utilizing the principle of protein-dye binding. Anal Biochem

$227 \quad 72: 248-254$.

228 18. Ando T (1989) Ecology of termites-introduction to the tropical ecology. University

229 of Tokyo Press.

230

231 
$232 \quad$ Figure legends

233

234 Fig. 1. Cellulase activities in Lake Furen. Activities were detected in 10\% SDS-PAGE

235 gel containing $0.5 \%$ carboxymethyl cellulose. The positions for molecular mass marker

236 proteins are shown by arrows. Lanes: 1, total sediment fraction; 2, meiobenthos

237 fraction; 3, Oligochaeta species; 4-7, morphologically distinct species of Nematode; 8,

238 Turbellaria species.

239

240 Fig. 2. Cellulase activities in the Biwase River. Ten percent SDS-PAGE gel containing

$0.5 \%$ carboxymethyl cellulose was used for the detection of cellulase bands of the

242 sediments, while $7.5 \%$ gel was used for Harpacticoida species. The positions for

molecular mass marker proteins are shown by arrows. Lanes: 1, total sediment fraction;

2, meiobenthos fraction; 3, Harpacticoida species.

Fig. 3. Cellulase activities in the Chinai River. Activities were detected in $10 \%$

SDS-PAGE gel containing $0.5 \%$ carboxymethyl cellulose. The positions for molecular mass marker proteins are shown by arrows. Lanes: 1, total sediment fraction; 2, meiobenthos fraction; 3 , Oligochaeta species. 
251 Fig. 4. Cellulase activities in the Kako River. Activities were detected in $10 \%$

252 SDS-PAGE gel containing $0.5 \%$ carboxymethyl cellulose. The positions for molecular

253 mass marker proteins are shown by arrows. Lanes: 1, total sediment fraction; 2 ,

254 meiobenthos fraction; 3, Harpacticoida species.

255 
(Figure 1)

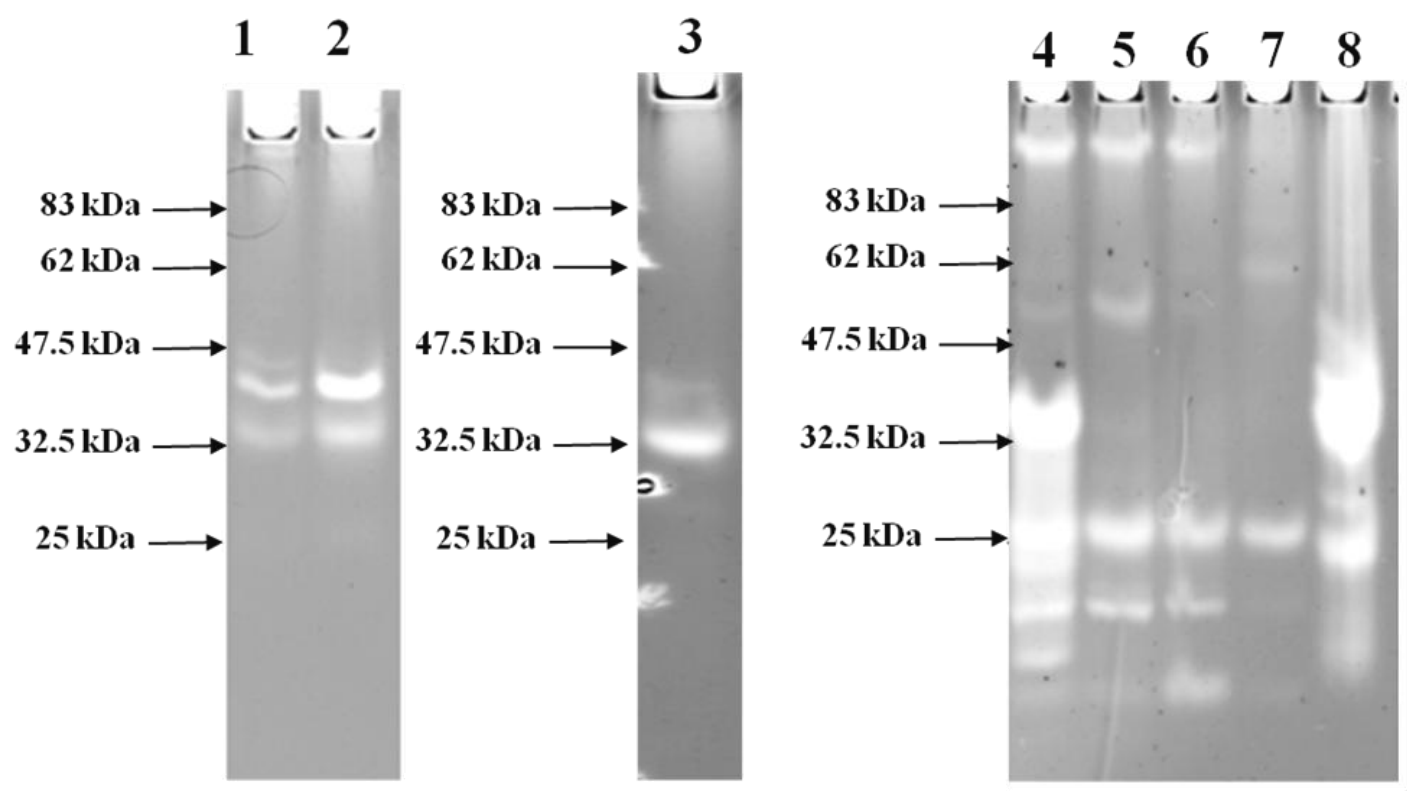


(Figure 2)

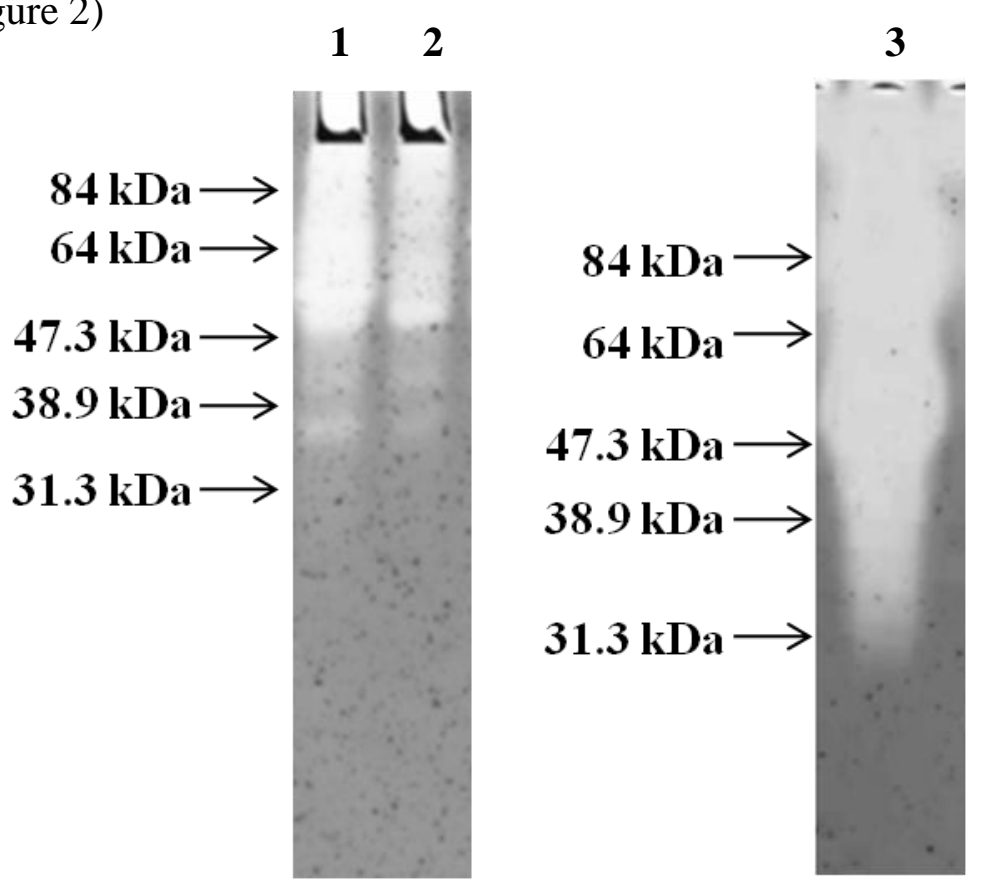


(Figure 3)

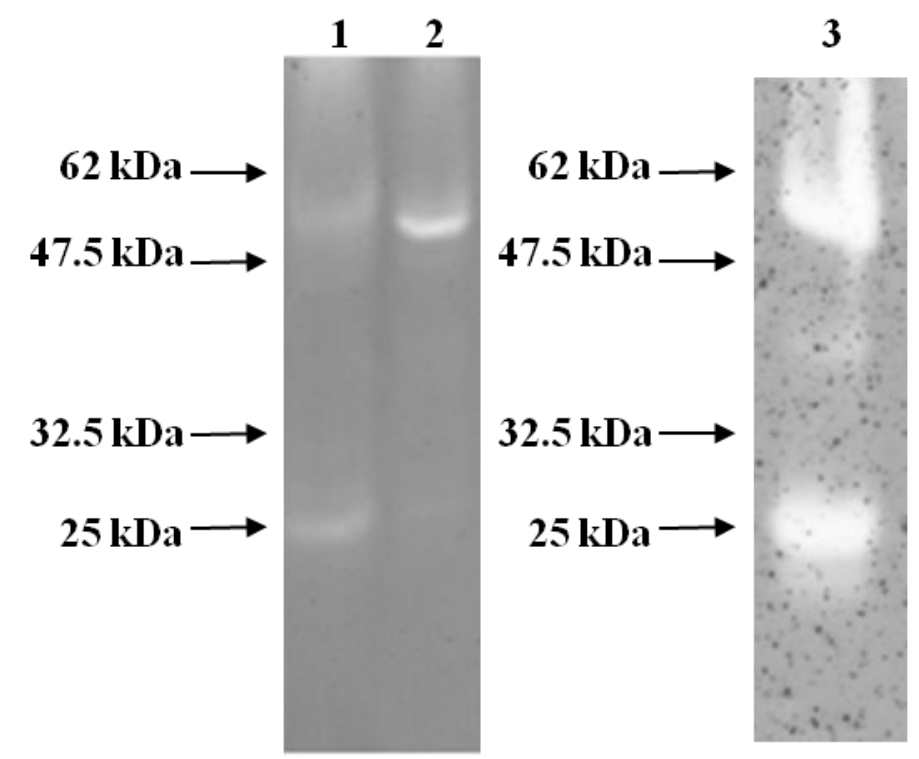


(Figure 4)

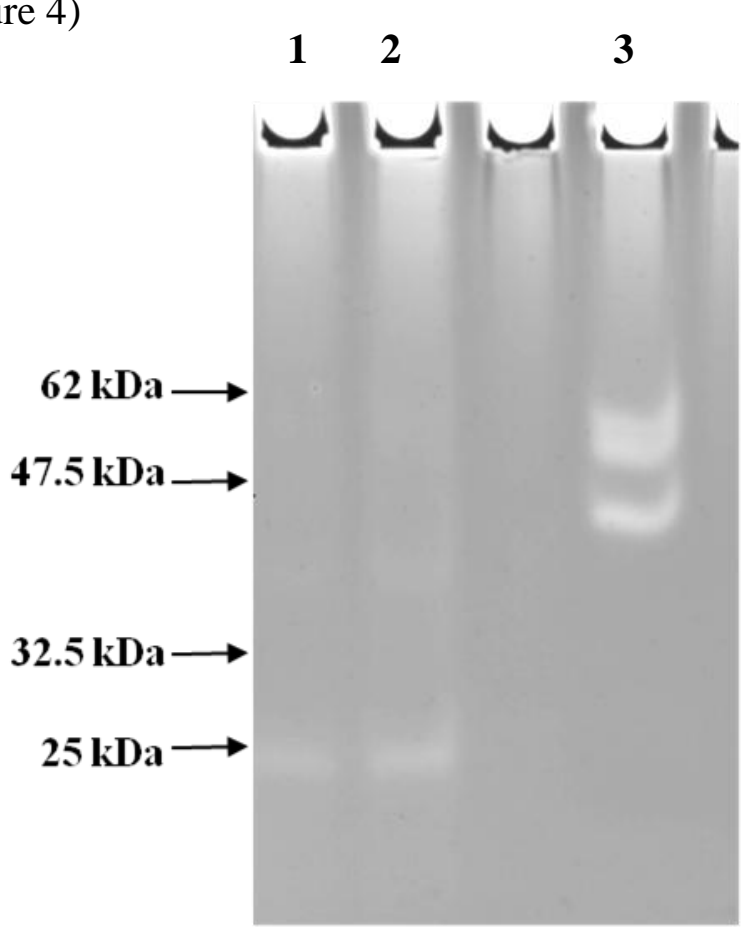


和文要旨

湿地帯に生息するメイオベントスのセルラーゼ活性

豊原治彦，朴 煐華，土屋佳奈子，劉 文（京大院農）

湿地帯におけるセルロース分解に関わるメイオベントスの役割を明らかにする 目的で, 琵琶瀬川と風連湖 (北海道), 知内川 (滋賀県), 加古川 (兵庫県) の 底泥に生息するメイオベントスのセルラーゼ活性を測定し，ほとんどのメイオ ベントスに活性を認めた。とくに風蓮湖，琵琶瀬川および知内川ではザイモグ ラフィー分析により, 底泥とメイオベントスの活性バンドのサイズが一致した ことから，これらの湿地带においてはセルロース分解にメイオベントスが主要 な役割を果たしていると考えられた。 